\title{
EVENT-STUDY EVIDENCE OF THE VALUE OF RELAXING LONGSTANDING REGULATORY RESTRAINTS ON BANKS, 1970-2000
}

\author{
Kenneth A. Carow \\ Edward J. Kane \\ Working Paper 8594 \\ http://www.nber.org/papers/w8594
NATIONAL BUREAU OF ECONOMIC RESEARCH
1050 Massachusetts Avenue
Cambridge, MA 02138
November 2001

The authors are respectively Assistant Professor of Finance at Indiana University, Kelley School of Business Indianapolis and James F. Cleary Professor in Finance at Boston College. They wish to thank David Ely and Philip Strahan for helpful comments on an earlier draft. The views expressed herein are those of the authors and not necessarily those of the National Bureau of Economic Research.

(C) 2001 by Kenneth A. Carow and Edward J. Kane. All rights reserved. Short sections of text, not to exceed two paragraphs, may be quoted without explicit permission provided that full credit, including $(\mathrm{C}$ notice, is given to the source. 
Event-Study Evidence of the Value of Relaxing Longstanding

Regulatory Restraints on Banks, 1970-2000

Kenneth A. Carow and Edward J. Kane

NBER Working Paper No. 8594

November 2001

JEL No. G28, D78, L51

\section{ABSTRACT}

In a partial-equilibrium model, removing a binding constraint creates value. However, in general equilibrium, the stakes of other parties in maintaining the constraint must be examined. In financial deregulation, the fear is that expanding the scope and geographic reach of very large institutions might unblock opportunities to build market power from informational advantages and size-related safety-net subsidies.

This paper reviews and extends event-study evidence about the distribution of the benefits and costs of relaxing longstanding geographic and product-line restrictions on U.S. financial institutions. The evidence indicates that the new financial freedoms may have redistributed rather than created value. Event returns are positive for some sectors of the financial industry and negative for others. Perhaps surprisingly, where customer event returns have been investigated, they prove negative.

Kenneth A. Carow

Kelley School of Business

Indiana University
Edward J. Kane

Department of Finance

Boston College

330A Fulton Hall

and NBER

edward.kane@bc.edu 
October 1, 2001

\section{EVENT-STUDY EVIDENCE OF THE VALUE OF RELAXING LONGSTANDING REGULATORY RESTRAINTS ON BANKS, 1970-2000*}

\section{Kenneth A. Carow \\ Edward J. Kane}

Thirty years ago, opportunities for U.S. banks to expand their geographic reach and product line were tightly constrained by charter limitations and by state and federal laws governing branch banking and holding-company affiliation. The idea that, within a single generation, large U.S. banks could become nation-spanning, superpowered financial conglomerates seemed an academic pipe dream.

In 1970, commercial banks could be distinguished from other kinds of financial institutions by two unique capacities: their right to offer demand deposits and their ability to make commercial loans. Restrictions on thrift, securities, insurance, and sales-finance companies made it hard for these and other kinds of nonbank institutions to offer close substitutes for banking's signature products.

This paper seeks to clarify how and why technological change undermined and finally demolished geographic and product-line constraints on U.S. financial institutions

and to review event-study evidence about the intersectoral distribution of the benefits and costs of relaxing particular restrictions. The evidence indicates that the demolition of these restraints intensifies public-policy concerns about the extent to which market power may be generated by large-bank mergers and safety-net subsidies that increase as an institution reaches megasize and megacomplexity.

\section{Financial-Institution Value Creation}

During the same 30-year interval, the conceptual foundations of financial intermediation theory similarly dissolved and reformed. The longstanding premise that banks are profitable because society assigns them a series of "special" rights and duties 
(cf. Tussing, 1967 and Corrigan, 1983) was displaced by the view that, even if it is not subsidized by special privileges, every financial institution can hope for special advantages from its access to scale ${ }^{1}$, scope $^{2}$. and network economies (see Katz and Shapiro, 1994; Economides, 1993) and to private information about its customers (Diamond, 1984; Fama, 1985). This access generates implicit returns that competitive pressure allocates between each institution and its counterparties (Kane and Malkiel, 1965). The stronger the competition for clients, the larger is the proportion of the rents generated by informational and network advantages that an institution is likely to share with customers.

Diamond (1984) explains how private information and monitoring costs influence a firm's choice between commercial loans and other public and private debt placements. If the firm is new or potentially very risky, high monitoring and policing costs can render public debt infeasible. Such firms can enhance their credit standing and transparency by submitting to monitoring and disclosure protocols devised by a high-quality bank. Only when changes in its degree of riskiness may be readily discerned by outside investors, can a new or risky firm economically issue marketable debt. For borrowers whose affairs are vulnerable to financial distress, maintaining a relationship with a bank that has developed a respected loan-workout capacity may also generate low-cost options for renegotiating credit terms. Evidence compiled by Chemmanur and Fulgheri (1994) supports this contention by indicating that firms that confront a high probability of financial distress are likely to choose bank credit over public debt.

Stock price reactions provide evidence of the value of informational assets to banks and their borrowers. James (1987) tests whether booking a bank loan conveys

\footnotetext{
* The authors are respectively Assistant Professor of Finance at Indiana University, Kelley School of Business Indianapolis and James F. Cleary Professor in Finance at Boston College. They wish to thank David Ely and Philip Strahan for helpful comments on an earlier draft.

${ }^{1}$ Evidence of economies of scale exists for many sectors of the financial industry: banking [Wheelock and Wilson, 2001, Hughes, Lang, Mester, and Moon, 1996]; savings banks [Chang and Lynge, 1994]; finance companies [Durkin and Elliehausen, 1998]; mortgage banking [Rossi, 1998]; property/casualty insurance [Hanweck and Hogan, 1996, Cummins and Weiss, 1993]; life insurance [Grace and Timme, 1992]; securities [Goldberge, Hanweck, Keenan, and Young, 1991]; and real estate [Zumpano, Elder, and Anderson, 2000].
} 
favorable information to the marketplace. He finds that borrower stock prices rise in response to the announcement of a bank loan agreement and fall in response to a private placement. Preece and Mullineaux (1994) confirm that borrowing firms also experience positive event-window returns from successfully negotiating loan agreements with nonbanks. Lummer and McConnell (1989) challenge the view that new loan agreements always convey benefits and establish that favorable revisions in an existing bank credit agreement definitely raise borrower stock prices. Best and Zhang (1993) show that new loan announcements do convey positive information when extensive monitoring is entailed.

Slovin, Johnson, and Glascock (1992) reinforce these findings about the value of private information by showing that small firms tend to benefit from maintaining a relationship with a bank. Berger and Udell (1995) study the implicit and explicit prices small firms pay for bank lines of credit. These authors find that borrowers with longerstanding relationships receive lower interest rates and are less likely to pledge collateral. When a bank refuses to pass on a fair share of a customer's informational rents, Houston and James (1996) confirm that switching to a new bank can allow a relationship customer to advantageously restructure its claim to informational rents.

By offering pre-issue certification and post-issue monitoring services that alleviate informational gaps, banks (Slovin and Young, 1990) and investment bankers (Smith, 1986; Booth and Smith, 1986; and Hansen and Torregrosa, 1992) smoothe a borrower's transition from private to public securities. The quality of an investment bank's certification services is bonded both by its desire to protect the reputational capital it has accumulated and by the liability imposed on it by the Securities Act of 1933 for achieving a fair offering price (Beatty and Ritter, 1986). Carter and Manaster (1990) and Johnson and Miller (1988) confirm the value of certification services by showing that an issuer receives a better price when its initial public offering (IPO) is managed by a prestigious investment bank.

\footnotetext{
${ }^{2}$ Evidence of economies of scope have been found by Berger, Hanweck, and Humphrey (1987); Berger, Hunter and Timme (1993); Berger, Humphrey, and Pulley (1996); Kanatas and Qi (1998); Barth, Caprio, and Levine (1999); Claessens and Klingebiel (2001).
} 
Evidence of the value of postloan monitoring by investment banks is of two types. The first looks for proof of customer satisfaction. Carter (1992) shows that firms whose IPO used a prestigious underwriter are less likely to employ a different underwriter when undertaking a secondary offering. The second explores correlations between underwriter prestige and long-run returns realized by IPO investors. Using investment-bank capital as a proxy for prestige, Michaly and Shaw (1994) find that IPOs managed by high-prestige investment bankers show less negative long-run returns than IPOs handled by other underwriters. Using several alternative measures of prestige, Carter, Dark, and Singh (1998) and Jain and Kini (1999) confirm the robustness of this finding. They show that the long-run performance of IPOs improves with the reputation of the underwriter.

When they are binding, regulatory restrictions on an institution's product line and geographic span limit its ability to use its private information, contracting skills, and network economies efficiently. For convenience, we term innovative expansions of an institution's product line as generating "cross-products." To the extent that scope economies exist, an institution can leverage its privately held information to design, market, and price cross-products more economically than at least some monoline firms. Similarly, to the extent that scale economies exist, large institutions can advantageously absorb less-efficient small institutions.

Even when they are successfully circumvented, restrictions on cross-product activity and interregional expansion generate circumvention costs that reduce the extent to which scope and scale economies can be realized. To an individual institution, the direct value of relaxing these restraints is the sum of incremental profits and diversification benefits generated by new cross-product business and the value of resources released by no longer having to service pre-existing cross-product business in a circumventive manner. If hit-and-run entry were possible, indirect effects would consist of reduced volume and margins for incumbent firms caused by the entry of cross-product suppliers.

In financial institution regulation, stakeholders include: regulators, taxpayers, competitors, depositors, debtholders, stockholders, and consumer and corporate loan customers. Different stakeholders are apt to be affected differently by the direct and 
indirect effects of any changes in regulatory regime. The difficulty of sorting out these stakes helps to explain why the political path to regulatory reform was a torturous one.

In what follows, we draw on evidence assembled in the event-study literature to explore the extent to which freeing up financial conglomerates to expand in size and scope may have created, destroyed, or merely redistributed value from other stakeholders to managers and stockholders of affected financial institutions.

\section{Evidence of Value Generated by Relaxing Geographic Constraints}

During the $19^{\text {th }}$ Century and most of the $20^{\text {th }}$, federal and state restrictions on the location of branches and affiliates constrained the geographic span and corporate structure of U.S. banking organizations (see, e.g., Kane, 1996). Prior to the last 30 years, whenever large banks opened loopholes in the fabric of interstate restriction, legislators usually worked to narrow them. Congress' final important effort in this direction took place in 1970 when it amended the Bank Holding Company Act of 1956 to restrict the affiliations and activities of nonbank subsidiaries of corporations owning a single bank. The preexisting one-bank holding company (OBHC) loophole allowed OBHCs to own subsidiaries in any business they wished and to locate them anywhere. Public-policy concern about this loophole came to the fore in July 1968, when Citigroup put itself into position to pass its operations through the loophole.

Statistical evidence of the value of this and other loopholes in banking regulation comes principally from studying imputed stock-price reactions to important regulatory and legislative "events." In an era when over 14,000 individual banks and many thousands of other depository institutions exist, these event studies inevitably focus on relatively small subsamples of banking and thrift companies whose stocks trade frequently. Although most researchers make every effort to broaden the range of their samples, it is important to acknowledge that effects on small and medium-size depository institutions and bank holding companies (BHCs) are markedly undersampled. We might also observe that the statistical significance of event returns is exaggerated somewhat by using confidence intervals rather than fiducial intervals. 
Eisenbeis, Harris, and Lakonishok (EHL, 1984) provide the first econometric measures of the OBHC loophole's value to stockholders. Comparing data for subsamples of 30 OBHCs, 35 multibank BHCs, and 13 autonomous banks, these authors document that the stock prices of Citicorp and its peer institutions experienced abnormal returns in the wake of Citi's announcing its OBHC strategy. While EHL attribute some of the gains to activity diversification, they also show that OBHCs appeared to derive benefit from the greater ease with which they could circumvent state branching restrictions. Institutions located in states that outlawed branch offices experienced higher returns than organizations residing in jurisdictions that authorized limited or statewide branching.

EHL also demonstrate that forming an OBHC earned a significantly positive return before the 1970 Amendments, but not afterwards. This tells us that the OBHC structure generated value as long as the loophole was open and reinforces the evidence that the 1970 Amendments significantly reduced the value of establishing new OBHCs. Interestingly, for existing $\mathrm{OBHCs}$, the give-and-take of the legislative process sustained much of their loophole value by grandfathering important OBHC privileges. Event studies of the 1970 Amendments by Aharony and Swary (1981) and Martin and Keown $(1981,1987)$ establish that existing OBHCs did not experience a negative event return. After 1970, bank lobbyists chipped away steadily at state-level restrictions on intrastate and interstate expansion. The impact of relaxing restrictions on out-of-state entry from a selection of designated or qualifying states has been studied extensively. Jayaratne and Strahan (1998) show that operating costs and loan losses decrease in states that authorize statewide branching and interstate banking because better-run banks expand at the expense of less-efficient rivals. Black, Fields, and Schweitzer (1990) show that authorizing out-of-state entry tends to benefit regional banks and to generate borderlinesignificant negative event returns for giant money-center banks. Looking at 35 state-level legislative events, Goldberg, Hanweck, and Sugrue (1992) find that the mean event return is insignificantly negative for in-state banks and significantly positive for non-moneycenter out-of-state institutions. Since potential target institutions figure to benefit from being exposed to an enriched set of acquirers, these results support the hypothesis that 
state-level deregulation of entry frequently benefited potential out-of-state acquirers in designated multistate regions at the expense of in-state acquirers and money-center banks.

To investigate this issue, Carow and Lee (1997) regress event returns on characteristics of individual banks and their home-state economic environments. Using a sample of 271 banking organizations, these authors find that: 1) money-center banks tend not to benefit from reciprocal arrangements for freer entry (reflecting the frequent exclusion of their headquarters states from regional banking compacts); 2) banks whose small size and capital positions are characteristic of acquisition targets show higher returns than banks with the characteristics of acquirers; 3) banks in states whose economies show high growth rates and low banking concentration [conditions that favor acquisition or branching deregulation (see Kroszner and Strahan, 1999)] show higher returns; and 4) reciprocal agreements that defer the trigger date and authorize de novo entry reduce the relative bargaining power of in-state target banks.

Carow and Heron (1998) and Brook, Hendershott, and Lee (1998) study abnormal returns generated by the Interstate Banking and Branching Efficiency Act of 1994 (IBBEA). Carow and Heron study the returns surrounding seven two-day event periods for a sample of $180 \mathrm{BHCs}$, half of which had already established interstate operations and half of which had not. Brook et al. study a 61-day event period for a sample of 290 banks. Consistent with Carow and Lee, both studies find that IBBEA events generate a positive abnormal return for BHCs and that abnormal returns prove higher for BHCs with targetlike characteristics. Carow and Heron also observe higher returns for banks headquartered in states that had previously refused to authorize interstate branching.

These studies indicate that improving opportunities for geographic expansion benefited some types of financial institutions. However, none of these studies determines how these putative benefits would be achieved. Theory suggests that the benefits of geographic expansion could be realized relatively efficiently by transactions in the market for corporate control.

\section{Sources of Gains to Acquirers and Targets in Combining Previously Autonomous Financial Services Firms}


Table 1 lists eight possible motives for one bank to acquire another. Economies of scale exist when the larger size of the post-acquisition enterprise permits it to garner more business or to produce services at a lower average cost than it could prior to the combination. Economies of scope exist when the revenues or costs for one or more particular services are enhanced when they are produced jointly with one or more other services. (Improved opportunities for diversification may be associated with expansions in either scope or scale). X-inefficiency exists to the extent that managers of the target were not operating their firm in a fully value-maximizing way. Market power is enhanced by any merger that improves the acquirer's ability to collect monopoly rents from the customer base. Managerial agency costs influence a deal whenever managers of the acquiring firm expect the acquisition to improve their personal welfare at the expense of shareholder interests. Safety-net scale and scope economies exist when increased institution size promises to increase the benefits an acquirer can derive from market conjectures that the acquirer has grown too big and too complex for regulators to fail and unwind or even to discipline adequately (TBTFU or TBTDA).

Event-study evidence on the value of removing state-imposed barriers to out-ofstate entry supports the hypothesis that removing geographic restrictions on bank expansion benefits potential acquirers by letting them assemble a customer base large enough to exhaust potential economies of scale and scope. However, conventional studies of scale and scope economies in banking find that economies are exhausted at an asset size and product mix well inside the median size and diversity of most of the banks included in the event-study samples (Berger, Hunter and Timme, 1993; Mitchell and Onvural, 1996). To reconcile these conflicting bodies of evidence, one must model the scale and scope economies generated by access to safety-net subsidies, as Hughes, Mester, and Moon, (2000) demonstrate.

Making room for larger (and potentially more diverse) competitors implies that the transition to the post-deregulation equilibrium market structure would require the exit of many existing competitors. With some firms facing elimination and others looking to grow and diversify, it is natural for stock markets to expect would-be survivors to explore opportunities to acquire the customer base of less-viable players. In line with this 
expectation, deregulation has been accompanied by a wave of mergers and acquisitions (M\&A) in the financial industry. According to the Vice Chairman of the Federal Reserve Board, a G-10 study found that during the 1990s financial firms consummated roughly 7,500 M\&A transactions, over half of them in the U.S. (Ferguson, 2001).

In nonfinancial combinations, event-study evidence indicates that abnormal returns generated by M\&A announcements tend to average slightly negative for acquirers and markedly positive for target firms (e.g., Lang, Stulz, and Walkling, 1989). Houston and Ryngaert (1994) and Houston, James, and Ryngaert (2001) report similar findings for the banking industry. Although some authorities attribute weakness in acquirer returns to empire building by managers of acquiring firms (Roll, 1986; Gorton and Rosen, 1995), such a weakness is also consistent with a model in which targets generally occupy a better bargaining position than acquirers (cf. Schwert, 2000; Wulf, 2000). Event-study evidence on reciprocal extensions of interstate entry supports the bargaining model, in that expanded opportunities for outside acquisition do not always benefit targets and often benefit potential out-of-state acquirers.

The applicability of the bargaining model to banking derives additional support from the event-study evidence compiled by Carow and his coauthors. These studies demonstrate that the division of abnormal returns between potential targets and acquirers in state-level events varies significantly with proxies for differences in bargaining power between different kinds of partners.

\section{Event Study Evidence on the Motives for Megabank Mergers:}

The patterns of target and acquirer returns observed are consistent with the hypothesis that M\&A activity helps mega-institutions in the U.S. to achieve three kinds of interacting benefits: scale and scope economies; market power; and safety-net subsidies. We review six such studies here.

Benston, Hunter and Wall (1995) calculate event returns for targets of 302 banking mergers and acquisitions between 1978 and 1986, looking for evidence to discriminate between the hypothesis that the acquirer is motivated by TBTDA subsidies as against earnings diversification. Although the authors hypothesize that their finding that a target's premium rises with its capital ratio favors the diversification motive over the risk-shifting 
motive, bargaining theory undermines this conjecture. Even if diversification benefits did not exist, a stronger capital position could be expected to increase a target's relative bargaining power and therefore its ability to force large acquirers to more fully shift TBTDA subsidies into the acquisition price.

Virtually every M\&A announcement includes management projections of the incremental profits the deal is expected to generate. Padgett (1999) reports that, in the megadeals of recent years, realized operating-cost reductions have averaged much less than management projections. Nevertheless, in a study of 41 large 1985-1996 banking combinations in which separate revenue and cost projections were disclosed, Houston, James and Ryngaert (2001) report that projected cost savings correlate significantly with consolidated acquirer and target stock returns, even though revenue projections do not. Houston et al. attribute the significant correlation to postmerger opportunities to cut operating costs and attribute the insignificance of revenue projections to management's failure to allow fully for deposit relationships lost in cost-saving branch closings. However, the post-combination cost savings these authors affirm need not be solely attributed to increased operating efficiency. They could equally well be due to reductions in financing costs occasioned by increases in size-related safety-net subsidies.

Kane (2000) argues that searches for TBTDA and market-power subsidies are apt to be contaminated by including deals in which the acquirer is not at least potentially a mega-institution. Focusing on the 15 largest BHC acquisitions in each of the years 19911998, he shows that stockholders of giant BHCs gain value from becoming more gigantic and gain even more value when the target is an in-state competitor.

Evidence that announcement of M\&A deals also significantly reduce risk-adjusted and maturity-adjusted yields on the uninsured debt of both acquirers and targets is compiled by Penas and Unal (2001). Consistent with the hypothesis that TBTFU/TBTDA benefits help to motivate large-bank mergers, combinations of medium-size banks whose consolidation pushes combined bank assets beyond a $\$ 100$ billion threshold produce particularly high announcement-month returns for their bondholders.

Researchers have not yet studied effects of large-bank mergers on the stock prices of corporate customers. However, banks that enhance their market power may be 
expected to extract monopoly rents. Compared to nonmerging banks, Prager and Hannan (1998) show that merging banks decrease retail deposit rates. This is consistent with an expansion either in market power or in size-related safety-net subsidies. Similar evidence emerges in the personal loan market. Kahn, Pennacchi, and Sopranzetti (2000) document that personal loan rates are higher in more concentrated markets and that mergers between large banks result in higher personal loan rates. In the highly contested market for automobile loans, however, mergers may increase efficiency. For this loan category, the authors find that consequential mergers lower loan rates.

\section{Pre-GLBA Event-Study Evidence on the Value of Cross-Product Restrictions}

The previous section developed evidence that megabanks frequently benefit from increased size and geographic extension. This section explores the extent to which expansion of product lines may unblock latent opportunities to build market power by intertwining large banks' information advantages and safety-net subsidies. Because these opportunities are peculiar to large financial firms, their influence on relative bargaining power would not make itself felt in combinations of nonfinancial firms.

Kwan and Laderman(1999) survey a large literature on the potential value to banking organizations of undertaking securities, insurance, and real-estate activities. Their findings are summarized in Table 2. While the thrust of the evidence varies somewhat with the time periods studied and how individual researchers measure risk and return, Kwan and Laderman conclude that opportunities for BHCs to achieve profitable portfolio diversification are strong in securities and reasonably likely in insurance. The Gramm-Leach-Bliley Act (GLBA) of 1999 finally opened these fields to BHCs and also opened banking to securities firms and insurance companies. However, the road leading up to this legislation exhibits many curves and milestones. Important entrance ramps had previously been opened de facto by regulatory arbitrage: i.e., from the dialectical interaction of bank efforts to circumvent Glass-Steagall and BHCA restrictions and regulatory competition for turf (see, e.g., Kane, 1984). In this dialectical back and forth, regulatees innovatively adapted their product line and corporate structure to disable the 
enforcement of statutory prohibitions and lobbied specialized regulators and Congressional committees to support or acquiesce in their circumventions.

To illustrate the secular progression in the pressure this dialectic exerted on Congress, this section distinguishes and examines examples of two kinds of pre-GLBA milestone events: those initiated by bank efforts to innovate across pre-existing industry borders ("cross-industry acquisition events") and regulator-initiated efforts to redraw industry borders ("section 20 events").

\section{Squeezing Securities Underwriting and Insurance Activity into Bank Product Lines}

1. The BankAmerica-Schwab Event. In November 1981, BankAmerica announced its intention to acquire Charles Schwab and Co. This event promised to make BankAmerica the first commercial bank to offer securities brokerage. Securities firms challenged this move by filing a protest with the Fed through their trade association, the Securities Industry Association. Although the dispute was not settled until the Supreme Court upheld the permissibility of the deal in June 1984, the Fed approved the takeover in January 1983. During the 14 months between the deal's announcement and Fed approval, 600 banks either found a way to initiate brokerage services or at least stated their intention to do so. National banks were assisted in their efforts by an OCC decision in August 1982 to authorize national banks to offer discount brokerage outside the BHC structure through an operating subsidiary of the bank.

Saunders and Smirlock (1987) analyze return and risk effects associated with the deal's announcement and subsequent Fed approval. Although the event presaged new opportunities for BHCs to realize scope and scale economies, event returns for these authors' sample of BHCs proved insignificantly different from zero while stocks of securities firms showed a significant 2 percent decline. Using the perspective supplied by Baumol's (1982) concept of contestable markets, we may infer that reducing barriers to BHC entry into brokerage services was seen as reducing the profit margins securities firms could enjoy without generating much in the way economic rents for BHC stockholders. 2. Section 20 Events. Beginning in 1987, the Fed used its regulatory authority under the BHC Act to authorize BHC subsidiaries (known popularly as "Section 20 subs") to underwrite classes of securities that it had previously held to be "bank-ineligible" (BI). 
The volume of BI business a Section 20 sub could book was limited by a strict cap on the percentage of the sub's gross revenue attributable to BI activity. The Fed initially set the revenue cap at 5 percent.

In April 1987, the Federal Reserve approved requests from Bankers Trust, Citicorp, and J.P. Morgan to underwrite four kinds of BI securities: commercial paper, asset-backed securities, mortgage-backed securities, and municipal revenue bonds.

During their first year of operation, these three firms' subs captured over 20 percent of the asset-backed securities market and approximately 2 percent of the mortgage-backed securities market. In 1989, the Fed increased the revenue cap to $10 \%$ and added corporate bonds and equities underwriting to the list of now-permissible BI activities.

Securities law prohibits the use of inside information for financial gain, while banking regulators are specifically directed to identify and eliminate unsafe and unsound practices. To insulate the bank and the safety net from risks taken in underwriting activities, the Fed initially placed stringent firewalls between the bank and its Section 20 affiliate. These barriers tightly restricted flows of information and resources between a bank and its underwriting arm. However, in August 1996, the Fed proposed to dismantle some of the firewalls and proceeded subsequently to accomplish this in a gradual manner. In October, the Fed allowed employees to work simultaneously for the BHC parent and the brokerage subsidiary. In December, the Fed increased the revenue limit from $10 \%$ to $25 \%$. In January 1997, the Fed proposed further firewall reductions. Finally, in August 1997, the Fed adopted its August proposal. Demolishing these firewalls shifted the burden of devising, monitoring, and enforcing substitute controls on managerial conflicts of interest from regulators to stockholders and customers.

Several studies analyze the wealth and risk effects of Section 20 events. Bhargava and Fraser (BF, 1998) analyze return and risk effects for banks and investment banks at four Section 20 event dates: (1) April 30, 1987, when the Fed authorized Bankers Trust, Citicorp, and Morgan to underwrite selected bank-ineligible securities; (2) January 18, 1989, when the Fed added corporate debt and equity securities to its permissible list; (3) September 13, 1989 when the Federal Reserve raised the revenue cap to 10\%; and (4) August 1, 1996, when the Fed proposed to raise the revenue cap again, this time to $25 \%$. 
Ely and Robinson (ER, 1998) look at event returns for the last event (which they date at a day earlier) and also for June 11 and December 20, 1996. On the June date, House Banking Committee Chairman James Leach urged the board to raise the revenue limit; on the December date, the Board announced its adoption of the $25 \%$ limit.

$\mathrm{ER}$ and $\mathrm{BF}$ employ slightly different sampling frames. BF sample the 50 largest publicly traded commercial-banking organizations and all publicly traded investment banks. They subdivide their banking subsample into three classes: BHCs with prior underwriting approval, banks that had an application pending, and other large banking firms. ER analyze a sample of 24 banking companies with Section 20 subs, 41 other banking organizations, and 20 investment banks.

On the initial-authorization date of April 30, 1987, the three BHCs winning permission and the six BHCs that had already submitted applications showed significant event gains of 1.23 percent and 0.70 percent, respectively. In contrast, portfolios constructed for investment banks and other large banking organizations show insignificant event returns. On the risk dimension, BHCs with applications approved or pending recorded a statistically significant increase in exposure to undiversifiable risk. Other commercial banks and investment banks showed no significant changes in risk. Apparently, the market expected that in pursuing the new opportunities a BHC would take on more diversifiable risk and benefit from doing so. Looking at different subsamples of banks on this same event date, Appilado, Gallo, and Lockwood (1993) report that the population of money-center banks and a sample of regional banks experienced gains of 1.60 percent and 1.46 percent, respectively.

On the date when corporate debt and equity underwriting became permissible (January 18, 1989), BF find that organizations with prior approval showed a significantly negative return and increased total risk. Other BHCs experienced significant gains, while investment-bank returns were not significantly affected. Apparently, at a time when the federal safety net was being tested by efforts to resolve the S\&L insurance mess, the power to underwrite corporate debt and equity was perceived as potentially poisonous fruit, apt to make the BHCs already engaged in cross-product underwriting riskier in ways that might not generate enough profit to support the increase. 
BF report that raising the revenue cap to 10 percent in August 1989 also significantly reduced returns for approved BHCs and insignificantly reduced them for the other BHCs. For their rougher partition, ER find no significant returns either on this date or on June 11. However, the meaning of the August 1989 event is contaminated by the safety-net implications of the concurrent passage of the Financial Institutions Reform, Recovery, and Enforcement Act of 1989 (FIRREA).

A related Section 20 event BF analyze is the Fed's August 1, 1996 proposal to raise the revenue cap to $25 \%$. This event is also contaminated, since the proposal coupled the cap increase with important firewall reductions. BF report insignificantly negative event returns for all BHC subsamples and insignificantly positive returns for investment banks. However, significant evidence of decreased risk emerges as well. Investment banks showed a decrease in total risk, while approved BHCs with Section 20 subs registered decreases in both total risk and in idiosyncratic risk.

The final section 20 event occurred in December 1996 when the Fed announced its adoption of the $25 \%$ limit (rather than the lesser amounts some analysts had conjectured). ER find that section 20 BHCs experienced a significant event return of $1.25 \%$, while securities firms and other banks showed an insignificant benefit of about 35 basis points. However, the signs test is significant, indicating that across individual firms in each subsample positive event returns predominated. ER also use regression methods to show that investment-bank returns for this event are explained by size and profitability characteristics associated with being a takeover target.

Cyree (2000) and Narayanan, Rangan, and Sundaram (NRS, this issue) cleverly neutralize the contaminating information in the Fed's August 1, 1996 proposal by adding an additional datapoint. They treat the cap-increase proposal as having been put in play when the American Bankers Association (ABA) first recommended it to the Fed. This assumption moves the revenue-cap proposal event forward --not to the Leach proposal date-- but to July 15, 1996. Combining this proposal date with the adoption date for the cap adjustment generates a significantly positive compound-event return for BHC portfolios and allows them to interpret August 1,1996 as predominantly a firewallsreduction proposal date. Event returns on this date suggest that, whatever positive effect 
was communicated by the Fed's endorsement of the ABA's proposal on August 1 was more than offset by the negative effect its firewalls-reduction proposal had on stockholder protections from managerial conflicts of interest.

NRS are the first to investigate whether financial-institution customers as well as investment banks might have been hurt by securities-powers expansion. NRS find that investment banks were sometimes harmed and sometimes helped by Section 20 events, but that the economic prospects of relationship customers at lead banks of sample BHCs were harmed in each event, usually significantly so.

This raises the question of how much of the harm customer firms experience reflects a long-run reduction in their ability to negotiate prices for relationship services and how much reflects an increased exposure as taxpayers to costs of financing safety-net subsidies. Monopoly power is an issue even though evidence assembled in Ang and Richardson (1994), Kroszner and Rajan (1997), and Puri (1994, 1996, 1999) indicate that in the short run bank entry made investment banking markets more competitive and improved spreads for customers. The danger is that, unless the contestability of securities markets is preserved for future entrants by controlling the distribution of network-size benefits and safety-net subsidies to mega-institutions, short-run benefits could be reversed in the long run. As Saunders (1999) notes, it may well be that "pro-competitive gains, resulting from Section 20 de novo entry into investment banking, will be rolled back" once the number of bank-unaffiliated investment bankers has shrunk substantially.

Contestable-markets theory tells us that entry discipline will be curtailed if TBTDA safety-net subsidies make it unreasonable for would-be new entrants to expect to force the exit of economically inefficient affiliates of large banks. This theory clarifies why and how TBTDA subsidies create market power. By sustaining unprofitable affiliates, safety-net subsidies discourage new entry by preventing the prompt exit of incumbent bank-affiliated competitors from lines in which they are earning below-market risk-adjusted returns. This marriage of market power and safety-net subsidies challenges authorities to respond promptly and conscientiously to evidence that large institutions benefit and customers might be harmed by cross-industry consolidation and particular changes in the regulatory regimes. 
3. OCC-Initiated Insurance Loopholes. Besides undermining the separation between banking and security activities, bank regulators authorized limited bank entry into insurance activities. Using its authority under the incidental-powers clause of the National Banking Act, the OCC authorized national banks to sell variable annuities and fixed-rate annuities in 1985 and 1990, respectively. The essence of these rulings was the opinion that annuity contracts are not insurance. In 1995, The Supreme Court upheld the OCC interpretation.

Carow (2001b) studies event returns on these three event dates. A related paper by Cowan, Howell, and Power (CHP, this issue) looks at event returns for the Supreme Court ruling and three other dates at which OCC loophole powers were tested or asserted: two appeals-court decisions preceding the Supreme Court decision and a 1994 OCC ruling that a national bank could structure an annuity as an insured deposit.

Carow samples life insurance companies, property/casualty companies, and banks. CHP sample life insurance companies and banks. Both papers observe negative event returns for insurance companies, but find different results for banks. In Carow's event window, banks fail to show an event return. In the events and sample of banks examined by CHP, returns for banks are significantly positive. Carow shows that only insurance companies that use an agency sales system were affected significantly; presumably the market thought brokerage companies could benefit from distributing bank-underwritten annuities. CHP find that over their event windows large life insurance companies with less capital recorded higher returns than other life companies.

One of the events CHP analyze is the OCC's approval of a so-called "retirement CD" designed by Blackfeet National Bank. The retirement CD sought explicitly to extend the deposit insurance safety net under an annuity product, potentially transfering wealth from taxpayers and insurance companies to banks. Lacking parallel guarantees, insurance companies would be hurt because they could not expect to price competitively an annuity product offering a comparable level of risk. Consistent with expanding safety-net guarantees, CHP find event returns highest for large banks with greater risk and event returns to be lowest for low-rated insurers with large annuity reserves. 
The OCC not only expanded bank annuity rights, but also a bank's right to sell a broad range of other insurance products. In 1986, the OCC expanded a longstanding small-town exception contained in the National Banking Act to permit any national bank or branch office located in a town whose population was 5,000 or less to sell insurance to customers located anywhere. In two separate rulings, the Supreme Court upheld the OCC's interpretation. Although the banks sampled showed no significant event returns, across these three dates, Carow (2001b) finds that life insurers and smaller insurance companies suffered substantial losses.

4. State-Level Extensions of Insurance Powers. State-chartered banks looked to state legislatures to keep national banks from eroding their franchise. By 1999, 15 states allowed banks to act as insurance brokers/agents and 5 states authorized underwriting activity. We found studies of only one state-level event of this type: a proposition ("Prop 103") approved by California voters on November 8, 1988. The proposition, which dealt principally with insurance pricing, included permission for state-chartered banks to become vendors of life, health, and property/liability insurance products. Shelor and Cross (1994) show that state-chartered banks benefited from the passage of Proposition 103, while federally chartered depository institutions showed no significant reaction. Although many authors find negative event returns from this event for insurance companies, this development cannot fairly be attributed to potential bank entry due to the contaminating effects of the pricing restrictions.

5. Other Cross-Industry Acquisition Announcements. Event study evidence on the effect of bank expansion into securities and insurance activities supports the twin possibilities of safety-net subsidies and increased market power. Expanding the safety net intensifies the potential for large institutions to use their increased market power to transfer wealth from taxpayers, competitors, and customers. Exploring this perspective, this section reviews event returns generated from cross-industry acquisitions.

In intensifying pressure to pass the GLBA, the single most important event was the Citicorp-Travelers combination. Johnston and Madura (2000) and Carow (2001a) examine announcement returns generated by this deal. 
Johnston and Madura (2000) divide their sample into three subsamples: large brokerage firms, large banks, and medium-sized banks. All subsamples show significantly positive event returns. Large banks and brokerage firms show the largest returns. We interpret these results as predicting two things: a near-certain end for GlassSteagall and BHCA restrictions on the insurance and securities activity of banking organizations and that larger institutions would be in a better position to benefit from this deregulation.

Carow (2001a) examines a different sample, one that excludes brokerage firms and focuses on size effects at banks and insurance companies. Although no statistically significant event return emerges for the average sample bank, a positive size effect is observed. In particular, event returns for banking institutions with assets greater than $\$ 10$ billion significantly exceed returns at smaller banks. Here, as elsewhere, the public-policy issue is the extent to which the apparent benefits trace to efficiency gains, increased market power, or safety-net expansion.

Prior to the Citicorp-Travelers event, BHCA restrictions on the ownership of U.S. banks by nonbank companies meant that most cross-industry acquisitions were initiated by BHCs as ways to enter the product markets of nonbank financial companies. BHC entry into nonbank markets tends to squeeze the margin of incumbent nonbank competitors. The standard pattern of event response was for competing nonbank companies to lose value and for the value of bank stocks either to be unaffected or to increase slightly.

Event returns generated by BHC acquisitions of securities firms have been studied most extensively. Davidson, Hatfield, and Glascock (1994) analyze acquisitions of brokerage houses, comparing event returns across three classes of acquirer: other brokerage houses, BHCs, and nonfinancial firms. Positive event returns emerge only for acquirers that are already in the brokerage business. BHC and nonfinancial acquirers fail to show significant returns.

Mergers and acquisitions of European financial firms are studied by Cybo-Ottone and Murgia (2000). Sampling 1988-1997 deals announced between large European financial institutions, these authors find the combined event return of acquirers and targets to be significant. However, when they partition results by country and industry, 
significant gains emerge only for bank-on-bank combinations within a given country and for deals that enable a bank to enter insurance. In contrast, unions of European banks with securities firms or foreign institutions fail to produce significant returns.

Kryzanowski and Ursel (1993) examine event returns in Canada, looking at the 1986-87 unfolding of provincial and federal permission for banks to become $100 \%$ owners of securities firms ("permission events") and at 1987-89 announcements of bank takeovers of investment dealers ("takeover announcements"). Across the sample of dealers studied, only one permission event generates a significantly positive return; no permission event significantly affects any sample bank. Most bank acquisitions of investment dealers show insignificant negative returns for the acquiring bank and insignificant positive returns for the target. However, when cumulated across events, target and acquirer returns become significant.

\section{Effects of Enacting GLBA}

The Gramm-Leach-Bliley Act (GLBA) of 1999 endorses cross-sector mergers within the United States financial industry. Henceforth, financial conglomerates can compete in a regulatory environment that does not require circuitous methods to bypass government restrictions on product-line extension. Of course, banks still operate under important constraints. The GLBA continues the tradition established by the BHCA of 1956 and the 1970 Amendments of restricting acquisitions of a bank or bank holding company by a commercial firm. The GLBA even extends the reach of this tradition for the first time to unitary thrift holding companies. Previously, this organizational form allowed any commercial firm to own a single thrift institution. While no study directly tests the value of the unitary-thrift loophole, Carow and Heron (this issue) infer that its demise contributed to the reduction in stock value that thrifts experience from GLBA events. Whether this decline traces to reduced opportunities to privately diversify financial-services risk or reduced opportunities to benefit from safety-net subsidies is once more an open question.

While the GLBA closed the unitary-thrift loophole, it allows registered financial holding companies "to engage in commercial activities that the Federal Reserve determines to be complementary" to financial operations or to encompass the scope of 
activities necessary to provide merchant banking. Today, banks and bank holding companies are allowed to hold up to 4.9 percent of the voting shares in any commercial firm without regulatory approval.

Carow and Heron show that stockholders of large financial institutions gained substantially more from the passage of the GLBA than smaller institutions did. In Table 3, we use Narayanan, Rangan, and Sundaram's methods and their list of important 1997 borrowers to conduct a preliminary investigation of how the GLBA may have affected financial-institution customers ${ }^{3}$.

Our investigation focuses on two pivotal events in the GLBA's road to passage: the October 22, 1999 announcement of the Conference Committee agreement and the Travelers-Citicorp announcement of April 1998. In each case, we employ a three-day event window consisting of the event day and the trading days immediately before and after the event.

In each window, we edit the NRS sample by deleting individual firms whose inclusion might obscure the impact of the changing probability of final Congressional action. We decided that six conditions justified deletion. The deletion conditions we impose and the concerns they address are as follows:

1. returns missing during the 200 trading days preceding the event window (to more sharply benchmark the normal return);

2. stock failed to trade during at least 50 percent of the benchmarking period (to minimize the influences of nonsynchronous trades);

3. stock value of firm fell below one dollar during the benchmarking period (to eliminate firms in danger of being delisted);

4. absence of asset, debt, or earnings information on Compustat (relevant only in secondary tests);

5. news about the firms was reported during the three-day event window on either the Dow Jones News Retrieval Wireservice, PR Newswire, Business

\footnotetext{
${ }^{3}$ Readers should recognize the selection and survival bias this entails. Given the significance of our preliminary findings, we intend to update and extend the list of customers in future research.
} 
Newswire, or M2 Presswire (to minimize contamination by firm-specific events);

6. daily returns during any event window surpassed 15 percent in absolute value (on the grounds that such a strong move might well reflect unreported firmspecific news).

We calculate event returns as deviations from a single-index market model, using ordinary least squares ${ }^{4}$ and the CRSP value-weighted index to proxy returns on the market portfolio. To measure event returns, we employ Brown and Warner's $(1980,1985)$ standardized cumulative average event return. We also employ a z-statistic that offers a binomial test of the predominance of negatively or positively signed event returns and a test of the difference between two sample proportions (see Mason, Lind, and Marchal (1999, p. 326-330).

Table 3 investigates event returns for the GLBA event; Table 4 studies event returns for the Citicorp-Travelers event. Each table has five sections. Section A compares results for relationship customers with a control sample of other nonfinancial firms; Section B partitions the sample according to whether or not a firm is a customer of a Section 20 banking affiliate; Section $\mathrm{C}$ partitions the sample into two groups according to the size of its market capitalization; and Sections D and E seek to compare results for firms that might have more and less bargaining power in negotiating a bank loan. Customer Response to the GLBA Event. Table 3 investigates event returns for the passage of GLBA. Section A compares the mean event return for the nonfinancialcustomer sample identified by NRS with the mean return for all nonfinancial firms posting return data on CRSP. The customer sample shows a significant mean loss of 1.47 percent from the GLBA event and individual event returns are predominantly negative. These losses support the hypothesis of GLBA wealth redistribution. Expanding bank powers apparently harmed the prospects of BHC relationship customers more than other firms, inasmuch as bank customers show a significantly lower mean event return than the control

\footnotetext{
${ }^{4}$ Karafiath (1994) investigates effects of "event-clustering" by Monte Carlo procedures. He finds that OLS is well-specified in finite samples that include several industries and that, for sufficiently large crosssections, there is no advantage to using several other more complex estimators such as the Multivariate Regression Model.
} 
sample. The 4,487-firm control sample recorded an insignificant event return of - 0.68 percent and was more evenly divided between positive and negative responses than the customer sample. ${ }^{5}$ These findings reinforce the evidence of customer damage that NRS found for Section 20 events.

Following the lead of NRS, we also separate the sample by whether or not a firm is a customer of a Section $20 \mathrm{BHC}$. We find that non-Section 20 customers have lower returns (-2.05 percent) than Section 20 customers (-1.27 percent), but the difference is not statistically significant.

The market power that can be exerted on a relationship customer varies inversely with the negotiating power of the borrower. To proxy the ability of a firm to negotiate favorable prices and services, we look first at customer size. We arbitrarily define "largecap firms" as those whose outstanding stock exceeds $\$ 100$ million in market value. Consistent with the hypothesis that smaller firms have less negotiating power, small-cap firms show a mean event return of -1.71 percent compared to -1.17 percent for large-cap firms. However, these returns differ insignificantly from each other.

Conventional wisdom holds that credit-constrained firms would be most likely to be harmed by reduced competition. Sections D and E use Compustat data to identify subsamples of customer firms that might feel credit-constrained. We proxy credit constraint in two ways: by debt ratings (where these exist) and by debt-to-asset ratio. The hypothesis being tested is that the formation of financial conglomerates may reduce competition between public and private debt markets and between large and small institutions, allowing banks to adjust services or prices at customer expense.

Section $\mathrm{D}$ proxies credit constraint by credit rating. Because debt-rating data are spotty, incorporating them severely limits the size of the usable sample. Although the small sample sizes rob the result of significance, mean returns are almost two percentage points lower for low-rated firms. This suggests that the GLBA might have particularly harmed credit-constrained firms.

\footnotetext{
${ }^{5}$ The significance of the difference is not critical, since any firm is potentially a customer of a megabank. Also, although the market index averages returns on financial and nonfinancial firms, abnormal returns need not average zero across the market on an event day. Even when financial firms have positive abnormal returns, the average abnormal return of nonfinancial firms can be positive, too.
} 
Section E classifies firms by degree of debt usage. Measures of debt usage are frequent enough on Compustat that we lose only 11 members of the section A sample ${ }^{6}$. Firms whose debt-to-asset ratio exceeds the arbitrary limit of 10 percent show lower returns than firms with a smaller ratio, -1.74 percent as against -1.00 percent. Again, the difference is not significant.

These findings reaffirm the evidence of customer damage that NRS found for Section 20 events. In all but one of the cells examined, relationship customers are affected adversely. Most importantly, the mean adverse effect of each event is significant for the full sample. Despite smaller sample sizes, cumulative event returns are significant for several subsample cells and the signs test proves significant in the majority of cases. Only 33.87 percent of customer firms showed positive event returns during the GLBA passage event and only 37.34 percent showed positive returns during the Citicorp-Travelers event window.

Customer Response to the Citicorp-Travelers Event. Using the same sample partitions as Table 3, Table 4 looks at the event returns generated by the Citicorp-Travelers announcement. Because the sample screens delete fewer cases, sample sizes are slightly larger than in the previous table.

In this event firms that were not classified as "relationship customers" fare marginally worse than relationship customers do. Among relationship customers, those with large caps, high debt usage, and a section 20 BHC relationship suffer significant losses.

Tables 3 and 4 analyze value-weighted returns. For the GLBA Passage Event, the same magnitude and pattern of significant results emerge whether we look at equalweighted or value-weighted returns. However, in the Citicorp-Travelers event, equalweighted event returns are generally smaller in magnitude and never statistically significant. Achieving greater importance in the value-weighted metric is consistent with the hypothesis that the Citi-Travelers combination threatened large customers more than small ones. Giant financial institutions would be able to expand their political clout, build

\footnotetext{
${ }^{6}$ The 11 firms omitted have almost the same average returns as the original sample.
} 
market share, and price their services less favorably for any corporation too large to expect smaller financial institutions to handle their needs.

Summary. Carow (2001) and Carow and Heron (2001) show that both events generated larger positive event returns for very large financial institutions than for smaller ones.

This GLBA event-study evidence suggests: (1) that GLBA events increased the bargaining power in M\&A negotiations that very large bank acquirers enjoy relative to targets and (2) that financial conglomeration threatens to adversely affect nonfinancial customers. Our tests cannot distinguish how much nonfinancial corporations were harmed as counterparties to future bank transactions from how much they were harmed as taxpayers that might be asked to finance safety-net subsidies. Simply put, results are consistent with the twin hypothesis that relaxing product-line restraints decreased customer bargaining power and increased the economic and political clout of giant U.S. institutions. Megainstitutions' increased clout comes from opportunities to become even larger and more complex than ever before. Managements may use their clout economically to discourage new entrants and politically to weaken regulatory discipline and expand their access to safety-net subsidies.

\section{Summary and Implications}

Hypothesis testing is an endless learning process. Evidence produced by studies of how bank stock returns respond to regulatory, legislative, and M\&A events is suggestive and provisional rather than decisive. Still, most public-policy economists would sleep better if the value bank stockholders have gained from new regulatory freedoms could be traced with great likelihood to opportunities for financial firms to jettison redundant staff and facilities. Unfortunately, the preponderance of the evidence reviewed here favors the alternative working hypothesis that extending the geographic reach and product lines of large U.S. banking organizations has at least temporarily diluted the combined impact of regulatory, creditor, and competitive discipline that mega-institutions confront.

Event-study evidence shows that, except where new problems of corporate governance have been created, stockholders of large U.S. banks have usually gained when restrictions on geographic and product expansion have been relaxed. Relaxing a binding 
constraint is bound to increase welfare in a partial-equilibrium model. However, in a general-equilibrium context, the benefits bank stockholders gain from restraint relaxation may come entirely at the expense of competitors, customers, and the general taxpayer.

Event studies of rulings that authorized large banks to enter securities and insurance markets typically show that stockholders of incumbent competitors in these markets lost value. This could be because bank entry was expected to improve product prices, which would generate value for customers. However, although effects on customers have been examined for only a few events, results so far are disturbing. Narayanan, Nanda, and Sundaram (this issue) show that relationship customers at banks lost value as BHC securities powers expanded. Tables $3 \& 4$ of our paper show that GLBA-passage and Citicorp-Travelers announcement events hurt corporate customer stocks as well. Finally, Prager and Hannan (1998) and Kahn, Pennacchi, and Sopranzetti (2000) offer evidence that consequential bank mergers harm consumers by decreasing deposit rates and increasing personal loan rates.

If operating-cost reductions were the predominant source of event gains from removing regulatory restraints and effecting megabank mergers, one would expect relationship customers to benefit along with bank stockholders. However, researchers have found that customers lost value in the few instances in which the customers' stake in deregulation events has been examined. Future research should investigate how consistently this result carries over to other deregulation events.

The theory of contestable markets indicates that the entry barriers that TBTDA safety-net subsidies create for other entrants generate monopoly power for megabanks in every market in which they participate. The TBTDA hypothesis also predicts that events that presage or announce increases (decreases) in FDIC deposit-insurance premiums would lower (raise) returns on the stock of large and more-leveraged institutions more than it would affect the stock of other banking firms. Across ten 1990-1991 premiumincrease events and five 1993-1995 premium-decrease events, this is the pattern that Biswas, Fraser, and Hebb (2000) observe.

Of course, Fed officials repeatedly deny that any institution is too big to fail. But what else could they say? If they were to confirm the existence of a universe of TBTFU 
banks, creditors and depositors would have little reason to monitor and police the risk exposures of the institutions so designated. By denying the obvious fact that some banks are too large, too complex, and too well-connected to discipline adequately, officials at least manage to maintain constructive ambiguity about where individual banks and BHCs stand along the TBTFU/TBTDA continuum. That the limits of safety-net support are ambiguous by no means contradicts the hypothesis that TBTDA benefits exist for most major institutions and that these benefits intensify sharply whenever a mega-institution becomes notably larger or more diverse. 


\section{REFERENCES}

Aharony, Joseph, and Itzhak Swary, 1981. Effects of the 1970 Bank Holding Company Act: Evidence from Capital Markets. The Journal of Finance 36, 841-853.

Ang, James and Terry Richardson, 1994. The Underwriting Experience of Commercial Bank Affiliates Prior to the Glass-Steagall Act: A Reexamination of Evidence for Passage of the Act. Journal of Banking and Finance 18, 351-396.

Apilado, Vincent P., John G.Gallo, and Larry J. Lockwood, 1993. Expanded Securities Underwriting: Implications for Bank Risk and Return. Journal of Economics and Business 45, 143-158.

Barth. James R., Gerard Caprio Jr., and Ross Levine, 1999. Banking Systems around the Globe: Do Regulation and Ownership Affect Performance and Stability? Policy Research Working Paper 2325. World Bank. Development Research Group, Washington, D.C. Processed.

Baumol, William J., 1982. Contestable Markets: An Uprising in the Theory of Industry Structure. American Economic Review 72, 1-15.

Beatty, Randolph P and Jay R. Ritter, 1986. Investment Banking, Reputation, and the Underpricing of Initial Public Offerings. Journal of Financial Economics 15, 213 232.

Benston, George J., William C.Hunter, and Larry D. Wall, 1995. Motivations for Bank Mergers and Acquisitions: Enhancing the Deposit Insurance Put Option Versus Earning Diversification. Journal of Money, Credit, and Banking 27, 777-788.

Berger, Allen N., G.A. Hanweck, and D.B. Humphrey 1987. Competitive Viability in Banking: Scale, Scope, and Product Mix Economies. Journal of Monetary Economics 20, 501-520.

Berger, Allen N., William C. Hunter, and Stephen G. Timme. 1993. The Efficiency of Financial Institutions: A Review of Research Past, Present, and Future. Journal of Banking and Finance 17, 221-249. 
Berger, Allen N, Humphrey, David B., Pulley, Lawrence B., 1996. Do Consumers Pay for One-Stop Banking? Evidence from an Alternative Revenue Friction. Journal of Banking \& Finance 20, 1601-1621.

Berger, Allen N., William C. Hunter, and Stephen G. Timme, 1993. The Efficiency of Financial Institutions: A Review and Preview of Research Past, Present, and Future. Journal of Banking and Finance 17, 221-249.

Berger, Allen N., and Gregory F. Udell, 1995. Relationship Lending and Lines of Credit in Small Firm Finance. The Journal of Business 68, 351-381.

Best, Ronald, and Hang Zhang, 1993. Alternative Information Sources and the Information Content of Bank Loans. The Journal of Finance 48, 1507-1522.

Bhargava, Rahul, and Donald R. Fraser, 1998. On the Wealth and Risk Effects of Commercial Bank Expansion into Securities Underwriting: An Analysis of Section 20 Subsidiaries. Journal of Banking \& Finance 22, 447-466.

Biswas, Rita, Donald R. Fraser, and Gregory Hebb, 2000. On the Shareholder Wealth Effects of Deposit Insurance Premium Revisions on Large Publicly Traded Commercial Banks. Journal of Financial Research 23, 223-241.

Black, Harold A., M. Andrew Fields, and Robert L. Schweitzer. Changes in Interstate Banking Laws: The Impact on Shareholder Wealth. The Journal of Finance 45, 1663-1672.

Booth, James R. and Richard L. Smith, 1986. Capital Raising, Underwriting and the Certification Hypothesis. Journal of Financial Economics 15, 261-281.

Brook, Yaron, Robert Hendershott, and Darrell Lee, 1998. The Gains from Takeover Deregulation: Evidence from the End of Interstate Banking Restrictions. Journal of Finance 53, 2185-2204.

Brown, Stephen and Jerold Warner, 1980. Measuring Stock Price Information. Journal of Financial Economics 8, 205-258.

Brown, Stephen and Jerold Warner, 1985. Using Daily Stock Returns: The Case of Event Studies. Journal of Financial Economics 14: 3-31.

Carow, Kenneth A., 2001a. The Citicorp - Traveler's Merger: Challenging Barriers Between Banking and Insurance. Journal of Banking and Finance 25, 1553-1571. 
Carow, Kenneth A., 2001b. The Wealth Effects of Allowing Bank Entry into the Insurance Industry. Journal of Risk and Insurance 68, 129-150.

Carow, Kenneth A., and Randall A.Heron, 2001. Capital Market Reactions to the Passage of the Financial Services Modernization Act of 1999. Quarterly Review of Economics and Finance, this issue.

Carow, Kenneth A., and Randall A. Heron, 1998. The Interstate Banking and Branching Efficiency Act of 1994: A Wealth Event for Acquisition Targets. Journal of Banking \& Finance 22, 175-196.

Carow, Kenneth A., and Winson B. Lee, 1997. State Passage of Interstate Banking Legislation: An Analysis of Firm, Legislative, and Economic Characteristics. Journal of Banking \& Finance 21, 1017-1043.

Carter, Richard B. 1992. Underwriter Reputation and Repetitive Public Offerings. The Journal of Financial Research 15, 341-354.

Carter, Richard B., Frederick H. Dark, and Ajai K. Singh, 1998. Underwriter Reputation, Initial Returns, and the Long-Run Performance of IPO Stocks. The Journal of Finance 53, 285-311.

Carter, Richard, and Steven Manaster, 1990. Initial Public Offerings and Underwriter Reputation. The Journal of Finance 45, 1045-1067.

Chang, C. Edward, and Lynge, Morgan J Jr., 1994. An Empirical Examination of Scale and Scope Economics of US Savings Banks. American Business Review 12, 100109.

Chemmanur, Thomas, and Paolo Fulghieri, 1994. Investment Bank Reputation, Information Production, and Financial Intermediation. The Journal of Finance 49, $57-79$.

Claessens, Stijn, and Daniela Klingebiel, 2001. Competition and Scope of Activities in Financial Services. The World Bank Research Observer. 16, 19-40.

Corrigan, Gerald, E., 1983. Banks are Special. New York: Federal Reserve Bank of New York. 
Cowan, Arnold, Jann Howell, and Mark Power, 2001. Wealth Effects of Banks' Rights to Market and Originate Annuities. Quarterly Review of Economics and Finance, this issue.

Cummins, J., David, and Weiss, Mary A., 1993. Measuring Cost Efficiency in the Property-Liability Insurance Industry. Journal of Banking \& Finance 17, 463-482.

Cybo-Ottone, Alberto, and Maurizio Murgia, 2000. Mergers and Shareholder Wealth in European Banking. Journal of Banking \& Finance 24, 831-859.

Cyree, Ken B., 2000. The Erosion of the Glass-Steagall Act: Winners and Loser in the Banking Industry. Journal of Economics and Business 52, 343-363.

Davidson, Wallace N. III, Gay Hatfield, and John L. Glascock, 1994. Common Stock Returns in Corporate Takeover Bids: The Case of Brokerage House Acquisitions. The Financial Review 29, 77-96.

Dermine, Jean, 1999. The Economics of bank Mergers in the European Union: A Review of the Public Policy Issues, Report Commissioned by Dutch Ministry of Finance, Fontainebleau: INSEAD.

Diamond, Douglas W., 1984. Financial Intermediation and Delegated Monitoring. Review of Economic Studies 51, 393-414.

Durkin, Thomas A., Elliehausen, Gregory E., 1998. The Cost Structure of the Consumer Finance Industry. Journal of Financial Services Research 13, 71-86.

Economides, Nicholas, 1993. Network Economics with Applications to Finance. Financial Markets, Institutions and Instruments 2, 89-97.

Eisenbeis, Robert A., Robert S. Harris, Josef Lakonishok, and Stephen J. Brown, 1984. Benefits of Bank Diversification: The Evidence from Shareholder Returns/Discussion. The Journal of Finance 39, 881-894.

Ely, David P., and Kenneth J. Robinson, 1998. How Might Financial Institutions React to Glass-Steagall Repeal?: Evidence from the Stock Market. Federal Reserve Bank of Dallas, Financial Industry Studies (September), 1-11.

Fama, Eugene F., 1985. What's Different About Banks? Journal of Monetary Economics $15,29-39$. 
Ferguson, Roger W., Jr., 2001. Technology and Financial Consolidation. The Ledger, Georgetown University Capital Markets Research Center, 1, 8-9.

Goldberg, Lawrence G., Hanweck, Gerald A., Keenan, Michael, and Young, Allan 1991. Economies of Scale and Scope In the Securities Industry. Journal of Banking \& Finance 15, 91-108.

Goldberg, Lawrence G., Gerald A. Hanweck, and Timothy F. Sugrue, 1992. Differential Impact on Bank Valuation of Interstate Banking Law Changes. Journal of Banking \& Finance 16, 1143-1158.

Gorton, Gary, and Richard Rosen, 1995. Corporate Control, Portfolio Choice, and the Decline of Banking. Journal of Finance, 50, 1377-1420.

Grace, Martin F., and Timme, Stephen G., 1992. An Examination of Cost Economies in the United States Life Insurance Industry. Journal of Risk and Insurance 59, 72 104.

Hansen, Robert S. and Paul Torregrosa, 1992. Underwriter Compensation and Corporate Monitoring. The Journal of Finance 47, 1537-1555.

Hanweck, Gerald A., and Hogan, Arthur m B., 1996. The Structure of the Property/Casualty Industry. Journal of Economics and Business 48, 141-156.

Houston, Joel F., Christopher M. James, and Michael D. Ryngaert, 2001. Where Do Merger Gains Come From?: Bank Mergers from the Perspective of Insiders and Outsiders. Journal of Financial Economics 60, 285-331.

Houston, Joel, and Christopher James, 1996. Bank Information Monopolies and the Mix of Private and Public Debt Claims. The Journal of Finance 51, 1863-1889.

Houston, Joel F., and Michael D. Ryngaert, 1994. The Overall Gains from Large Bank Mergers. Journal of Banking \& Finance 18, 1155-1176.

Hughes, Joseph p., Lang, William, Mester, Loretta J., and Moon, Choon-Geol 1996. Efficient Banking Under Interstate Branching. Journal of Money, Credit, and Banking 28, 1045-1071.

Hughes, Joseph P., Loretta J. Mester, and Choon-Geol Moon, 2000. Are Scale Economies Elusive or Illusive?: Evidence Obtained by Incorporating Capital Structure and Risk-Taking into Models of Bank Production, Rutgers University (unpublished). 
Jain, Bharat A., and Omesh Kini, 1999. On Investment Banker Monitoring in the New Issues Market. Journal of Banking \& Finance 23, 49-84.

James, Christopher, 1987. Some Evidence on the Uniqueness of Bank Loans. Journal of Financial Economics 19, 217-235.

Jayaratne, Jith, and Philip E. Strahan, 1998. Entry Restrictions, Industry Evolution, and Dynamic Efficiency: Evidence from Commercial Banking. Journal of Law and Economics 41, 239-273.

Johnston, James and Jeff Madura, 2000. Valuing the Potential Transformation of Banks into Financial Service Conglomerates: Evidence from the Citigroup Merger. The Financial Review 35, 17-36.

Johnson, James M., and Robert E. Miller, 1988. Investment Banker Prestige and the Underpricing of Initial Public Offerings. Financial Management 17, 19-29.

Kahn, Charles, George Pennacchi, and Ben Sopranzetti, 2000. Bank Consolidation and Consumer Loan Interest Rates. Working Paper: The Wharton Financial Institutions Center.

Kanatas, George, and Jianping Qi, 1998. Underwriting by Commercial Banks: Incentive Conflicts, Scope Economies, and Project Quality. Journal of Money, Credit, and Banking 30, 119-133.

Kane, Edward J., 2000. Incentives for Banking Megamergers: What Motives Might Regulators Infer from Event-Study Evidence? Journal of Money, Credit, and Banking 32, 671-701.

Kane, Edward J., 1996. De Jure Interstate Banking: Why Only Now? Journal of Money, Credit, and Banking 28, 141-161.

Kane, Edward J., 1984. Technological and Regulatory Forces in the Developing Fusion of Financial-Services Competition. Journal of Finance 39, 759-773.

Kane, Edward J., and Burton G. Malkiel, 1965. Deposit Variability, Bank-Portfolio Allocation and the Availability Doctrine. Quarterly Journal of Economics, 79, 113-134. 
Karafiath, Imre, 1994. On the Efficiency of Least Squares Regression with Security Abnormal Returns as the Dependent Variable. Journal of Financial and Quantitative Analysis 29, 279-300.

Katz, Michael L., and Carl Shapiro, 1994. Systems Competition and Network Effects, Journal of Economic Perspectives 8, 93-95.

Kroszner, Randall S., and Raghuram G. Rajan, 1997. Organization Structure and Credibility: Evidence from Commercial Bank Securities Activities before the Glass-Steagall Act. Journal of Monetary Economics 39, 475-516.

Kroszner, Randall S., and Philip E. Strahan, 1999. What Drives Deregulation?: Economics and Politics of the Relaxation of Bank Branching Restrictions. Quarterly Journal of Economics 114, 1437-1461.

Kryzanowski, Lawrence, and Nancy Ursel, 1993. Market Reaction to Announcements of Legislative Changes and Canadian Bank Takeovers of Canadian Investment Dealers. Journal of Financial Services Research 7, 171-185.

Kwan, Simon H., and Elizabeth S. Laderman, 1999. On the Portfolio Effects of Financial Convergence: A Review of the Literature. Economic Review, Federal Reserve Bank of San Francisco, 18-31.

Lang, Larry H., Rene M. Stulz, and Ralph A. Walkling, 1989. Mangagerial Performance, Tobin's Q, and the Gains from Successful Tender Offers. Journal of Financial Economics 24, 137-154.

Lummer, Scott L., and John J. McConnell, 1989. Further Evidence on the Bank Lending Process and the Capital-Market Response to Bank Loan Agreements. Journal of Financial Economics 25, 99-122.

Martin, John D., and Arthur J. Keown, 1981. Market Reaction to the Formation of OneBank Holding Companies. Journal of Banking \& Finance 5, 383-393.

Martin, John D., and Arthur J. Keown, 1987. One-Bank Holding Company Formation and the 1970 Bank Holding Company Act Amendment: An Empirical Examination Allowing for Industry Group Effects. Journal of Banking \& Finance 11, 213-221. Mason, Robert D., Douglas A. Lind, and William G. Marchal, 1999. Statistical Techniques in Business and Economics, Irwin McGraw-Hill. 
Michaly, Roni, and Wayne Shaw, 1994. The Pricing of Initial Public Offerings: Tests of Adverse Selection and Signaling Theories. The Review of Financial Studies 7, 279-319.

Mitchell, Karlyn, and Nur M. Onvural, 1996. Economies of Scale and Scope at Large Commercial Banks: Evidence from the Fourier Flexible Functional Form. Journal of Money, Credit, and Banking 28, 178-199.

Narayanan, Rajesh, Rangan Nanda, and Sridhar Sundaram. 2001. Relaxing GlassSteagall: Welfare Implications of Bank Entry into Securities Underwriting. Quarterly Review of Economics and Finance, this issue.

Padgett, Tania, 1999. Big Mergers Yielding Profit Letdowns, Study Finds. American Banker 164, (October 12), 1 and 37.

Penas Maria F., and Haluk Unal, 2001. Too-Big-to-Fail Gains in Bank Mergers: Evidence from the Bond Markets. Department of Finance, University of Maryland (unpublished).

Prager, Robin A. and Timothy H. Hannan, 1998. Do Substantial Horizontal Mergers Generate Significant Price Effects? Evidence from the Banking Industry. Journal of Industrial Economics 46, 433-52.

Preece, Dianna C., and Donald J. Mullineaux, 1994. Monitoring by Financial Intermediaries: Banks vs. Nonbanks. Journal of Financial Services Research 8 , 193-202.

Puri, Manju, 1994. The Long-term Performance of Bank Underwritten Security Issues. Journal of Banking and Finance 18, 397-419.

Puri, Manju, 1996. Commercial Banks in Investment Banking: Conflict of Interest or Certification Role? Journal of Financial Economics 40, 373-402.

Puri, Manju, 1999. Commercial Banks as Underwriters: Implications for the Going Public Process. Journal of Financial Economics 54, 133-163.

Roll, Richard, 1986. The Hubris Hypothesis of Corporate Takeovers, Journal of Business, 59, 197-216.

Rossi, Clifford V., 1998. Mortgage Banking Cost Structure: Resolving an Enigma. Journal of Economics and Business 50, 219-234. 
Saunders, Anthony, 1999. Consolidation and Universal Banking, Journal of Banking and Finance 23, 693-695.

Saunders, Anthony, and Michael Smirlock, 1987. Intra- and Interindustry Effects of Bank Securities Market Activities: The Case of Discount Brokerage. Journal of Financial and Quantitative Analysis 22, 467-482.

Schwert, G. William, 2000. Hostility in Takeovers: In the Eyes of the Beholder, Journal of Finance, 55, 2599-2640.

Shelor, Roger M., and Mark L. Cross, 1990. Insurance Firm Market Response to California Proposition 103 and the Effects of Firm Size. Journal of Risk and Insurance 57, 682-690.

Slovin, Myron B., Shane A. Johnson, and John L. Glasock, 1992. Firm Size and the Information Content of Bank Loan Announcements. Journal of Banking \& Finance 16, 1057-1071.

Slovin, Myron B., and John E. Young, 1990. Bank Lending and Initial Public Offerings. Journal of Banking \& Finance 14, 729-740.

Smith, Clifford W., 1986. Investment Banking and the Capital Acquisition Process. Journal of Financial Economics 15, 3-29.

Tussing, A. Dale, 1967. The Case for Bank Failure. Journal of Law and Economics, 10, 129-147.

Wheelock David C., and Wilson, Paul W., 2001. New Evidence on Returns to Scale and Product Mix Among US Commercial Banks. Journal of Monetary Economics 47, 653-674.

Wulf, Julie, 2000. Do CEOs of Target Firms Trade Power for Premiums?: Evidence from Mergers of Equals, unpublished draft: the Wharton School, University of Pennsylvania (April).

Zumpano, Leonard V., Elder, Harold W., and Anderson, Randy I., 2000. The Residential Real Estate Brokerage Industry: An Overview of Past Performance and Future Prospects. The Journal of Real Estate Research 19, 189-207. 


\title{
TABLE 1: POSSIBLE ECONOMIC JUSTIFICATIONS FOR ACQUIRING
} ANOTHER BANK

\author{
Cost-Based Economies of Scale \\ Brand-Based Economies of Scale \\ Revenue-Based Economies of Scale \\ Safety-Net-Based Economies of Scale \\ Revenue-Based Economies of Scope \\ $\mathrm{X}$-Efficiency \\ Market Power \\ Managerial Agency Costs
}

- Pursuit of size to strengthen managerial entrenchment

- Pursuit of size-based increased in executive salaries

Source: Kane (2000), as adapted from Dermine (1999). 


\section{TABLE 2: RISK AND RETURN CHARACTERISTICS OF SELECTED NONBANK ACTIVITIES}

\begin{tabular}{|c|c|c|c|}
\hline \multirow[b]{2}{*}{ Activity } & \multicolumn{2}{|c|}{ Relative to Banking } & \multirow{2}{*}{$\begin{array}{l}\text { Potential Effect on BHC } \\
\text { Risk of Engaging } \\
\text { in Nonbank Activity }\end{array}$} \\
\hline & Profitability $^{2}$ & Risk $^{3}$ & \\
\hline \multicolumn{4}{|l|}{ Securities $^{4}$} \\
\hline Overall & Higher & Higher & Varies $^{5}$ \\
\hline Primary Dealers & Lower & Higher & Decrease \\
\hline Non-primary dealers & Same & Higher & Decrease \\
\hline Underwriting $^{6}$ & Varies $^{7}$ & Higher & Decrease \\
\hline Primary Dealers & Same & Higher & Decrease \\
\hline Non-primary dealers & Lower & Higher & Decrease \\
\hline Trading & Higher & Higher & Varies $^{7}$ \\
\hline Primary Dealers & Higher & Higher & Decrease \\
\hline Non-primary dealers & Higher & Higher & Increase \\
\hline Bank-eligible Securities & Higher & Higher & Decrease \\
\hline \multicolumn{4}{|l|}{ Insurance } \\
\hline Agency & Higher & Varies $^{5}$ & Varies $^{8}$ \\
\hline \multicolumn{4}{|l|}{ Underwriting } \\
\hline Property \& Casualty & Higher & Varies $^{8}$ & Varies $^{8}$ \\
\hline Life & Varies $^{8}$ & Varies $^{5}$ & Varies $^{8}$ \\
\hline \multicolumn{4}{|l|}{ Real Estate } \\
\hline Agency & Higher & Higher & N.A. \\
\hline Development & Varies $^{9}$ & Varies $^{8}$ & Increase \\
\hline Direct Equity Investment & Varies $^{10}$ & Higher & Varies $^{10}$ \\
\hline Title Abstract & Higher & Varies $^{8}$ & N.A. \\
\hline Operators & Varies $^{5}$ & Varies $^{11}$ & N.A. \\
\hline Condominium & Lower & Higher & N.A. \\
\hline Management and Co-op & & & \\
\hline
\end{tabular}

Source: Kwan and Laderman (1999)

${ }^{1}$ The effect on banking-organization risk of engaging in the nonbank activity. "Decrease" indicates that there exists a nonzero weight on nonbank assets such that an organization with bank and nonbank assets has lower risk than an organization with only bank assets. However, there may not be a decrease in risk for all nonbank weights, and the maximum nonbank weight that permits a decrease in risk may be quite small. "Increase" indicates that all nonzero weights on the nonbank activity would increase banking organization risk.

${ }^{2}$ Some studies use accounting return on equity ROE and some use accounting return on assets ROA to measure profitability.

${ }^{3}$ Variance of ROE or ROA, coefficient of variation (standard deviation of returns divided by mean of returns) of ROE or ROA, or probability of bankruptcy.

${ }^{4}$ Except in the last item, securities activities involve bank-eligible and bank-ineligible securities.

${ }^{5}$ Depends on profitability or risk measure and, depending on the risk measure, may also depend on methodology of particular study.

${ }^{6}$ Underwriting, dealing, and brokerage. May also include provision of investment advice.

${ }^{7}$ Depends on whether data cover primary dealers or non-primary dealers.

${ }^{8}$ Depends on profitability or risk measure used.

${ }^{9}$ Depends on profitability measure and time period.

${ }^{10}$ Depends on whether REIT data or thrift service corporation data are used, and may also depend on time period and/or methodology.

${ }^{11}$ Depends on time period. 


\section{TABLE 3: EVENT RETURNS FOR THE GLBA PASSAGE EVENT \\ (OCTOBER 21, 22 AND 25, 1999)}

(Value-Weighted Returns)

\begin{tabular}{|c|c|c|c|c|c|}
\hline $\begin{array}{c}\text { Category of Bank } \\
\text { Customers }\end{array}$ & $N$ & $\begin{array}{c}\text { Abnormal } \\
\text { Return }\end{array}$ & T-Value & $\%$ Positive & $\begin{array}{l}\text { Z-statistic for } \\
\text { signs test }\end{array}$ \\
\hline \multicolumn{6}{|c|}{ Section A } \\
\hline $\begin{array}{l}\text { Relationship } \\
\text { Customers }\end{array}$ & 186 & $-1.47 \% * * *$ & -3.00 & $33.87 \%$ & $-8.43 * * *$ \\
\hline $\begin{array}{l}\text { Other Nonfinancial } \\
\text { Corporations }\end{array}$ & 4487 & $-0.68 \% * * *$ & -5.58 & $43.70 \%$ & $-8.43 * * *$ \\
\hline Difference in Means & & $-0.79 \% *$ & 1.83 & $-9.83 \%$ & $2.65 * * *$ \\
\hline \multicolumn{6}{|c|}{ Section B } \\
\hline $\begin{array}{l}\text { Customers of } \\
\text { Section } 20 \text { banks }\end{array}$ & 137 & $-1.27 \% * *$ & -2.21 & $33.58 \%$ & $-3.85 * * *$ \\
\hline $\begin{array}{l}\text { Customers of Non- } \\
\text { Section } 20 \text { banks }\end{array}$ & 49 & $-2.05 \% * *$ & -2.16 & $34.69 \%$ & $-2.14 * *$ \\
\hline Difference in Means & & $0.78 \%$ & 0.72 & $-1.11 \%$ & 0.14 \\
\hline \multicolumn{6}{|c|}{ Section $\mathrm{C}$} \\
\hline $\begin{array}{l}\text { Small cap } \\
\psi \$ 100 \text { mil equity }\end{array}$ & 106 & $-1.71 \% * * *$ & -2.72 & $33.96 \%$ & $-3.30 * * *$ \\
\hline $\begin{array}{l}\text { Large cap } \\
>\$ 100 \text { mil equity }\end{array}$ & 80 & $-1.17 \%$ & -1.45 & $33.75 \%$ & $2.91 * * *$ \\
\hline Difference in Means & & $-0.54 \%$ & 0.69 & -0.21 & 0.03 \\
\hline \multicolumn{6}{|c|}{ Section D } \\
\hline $\begin{array}{l}\text { Non-Investment } \\
\text { Grade Bond Rating }\end{array}$ & 21 & $-1.59 \%$ & -0.97 & $23.81 \%$ & -2.40 \\
\hline $\begin{array}{l}\text { Investment Grade } \\
\text { Bond Rating }\end{array}$ & 11 & $0.30 \%$ & 0.15 & $54.55 \%$ & 0.30 \\
\hline Difference in Means & & $-1.89 \%$ & 0.69 & $-30.74 \%$ & $1.74 *$ \\
\hline \multicolumn{6}{|c|}{ Section E } \\
\hline Debt/Assets $\zeta 10 \%$ & 113 & $-1.74 \% * *$ & -2.33 & $34.51 \%$ & $-3.29 * * *$ \\
\hline Debt/Assets $<10 \%$ & 62 & $-1.00 \% *$ & -1.87 & $32.26 \%$ & $-2.79 * * *$ \\
\hline Difference in Means & & $-0.74 \%$ & 0.11 & $2.25 \%$ & 0.30 \\
\hline
\end{tabular}

*** Significantly different from zero at 1 percent

** Significantly different from zero at 5 percent

* Significantly different from zero at 10 percent 


\section{TABLE 4: EVENT RETURNS FOR CITICORP-TRAVELERS ANNOUNCEMENT}

(APRIL 3, 6, AND 7, 1998) - (Value Weighted Returns)

\begin{tabular}{|c|c|c|c|c|c|}
\hline $\begin{array}{c}\text { Category of Bank } \\
\text { Customers }\end{array}$ & $N$ & $\begin{array}{c}\text { Abnormal } \\
\text { Return }\end{array}$ & T-Value & $\%$ Positive & $\begin{array}{l}Z \text {-statistic for } \\
\text { signs test }\end{array}$ \\
\hline \multicolumn{6}{|c|}{ Section A } \\
\hline $\begin{array}{l}\text { Relationship } \\
\text { Customers }\end{array}$ & 233 & $-1.00 \% * *$ & -2.22 & $37.34 \%$ & $-3.87 * * *$ \\
\hline $\begin{array}{l}\text { Other Nonfinancial } \\
\text { Corporations }\end{array}$ & 4966 & $-1.29 \% * * *$ & -16.91 & $35.38 \%$ & $-20.60 * * *$ \\
\hline Difference in Means & & $0.29 \%$ & 1.41 & $1.96 \%$ & 0.61 \\
\hline \multicolumn{6}{|c|}{ Section B } \\
\hline $\begin{array}{l}\text { Customers of } \\
\text { Section } 20 \text { banks }\end{array}$ & 176 & $-1.17 \% * *$ & -2.31 & $37.50 \%$ & $-3.32 * * *$ \\
\hline $\begin{array}{l}\text { Customers of Non- } \\
\text { Section } 20 \text { banks }\end{array}$ & 57 & $-0.45 \%$ & -0.43 & $36.84 \%$ & $-1.98 * *$ \\
\hline Difference in Means & & -0.72 & 0.77 & $0.66 \%$ & 0.09 \\
\hline \multicolumn{6}{|c|}{ Section C } \\
\hline $\begin{array}{l}\text { Small cap } \\
\psi \$ 100 \text { mil equity }\end{array}$ & 118 & $-0.67 \%$ & -0.75 & $43.22 \%$ & -1.47 \\
\hline $\begin{array}{l}\text { Large cap } \\
>\$ 100 \text { mil equity }\end{array}$ & 115 & $-1.33 \% * *$ & -2.40 & $31.30 \%$ & $-4.01 * * *$ \\
\hline Difference in Means & & $0.66 \%$ & 1.18 & $11.92 \%$ & $1.88 *$ \\
\hline \multicolumn{6}{|c|}{ Section D } \\
\hline $\begin{array}{l}\text { Non-Investment } \\
\text { Grade Bond Rating }\end{array}$ & 17 & $0.28 \%$ & 0.14 & $41.18 \%$ & 0.73 \\
\hline $\begin{array}{l}\text { Investment Grade } \\
\text { Bond Rating }\end{array}$ & 9 & $-1.63 \%$ & -1.60 & $33.33 \%$ & -1.00 \\
\hline Difference in Means & & $1.91 \%$ & 1.21 & $7.84 \%$ & 0.39 \\
\hline \multicolumn{6}{|c|}{ Section E } \\
\hline Debt/Assets $\zeta 10 \%$ & 134 & $-1.08 \% *$ & -1.71 & $38.06 \%$ & $-2.76 * * *$ \\
\hline Debt/Assets $<10 \%$ & 86 & $-0.88 \%$ & 1.46 & $34.88 \%$ & $-2.80 * * *$ \\
\hline Difference in Means & & $-0.20 \%$ & 0.08 & $-3.18 \%$ & 0.48 \\
\hline
\end{tabular}

*** Significantly different from zero at 1 percent

** Significantly different from zero at 5 percent

* Significantly different from zero at 10 percent 